\title{
Marburg Virus Infection in Egyptian Rousette Bats, South Africa, 2013-2014 ${ }^{1}$
}

\section{Janusz T. Pawęska, Petrus Jansen van Vuren, Alan Kemp, Nadia Storm, Antoinette A. Grobbelaar, Michael R. Wiley, Gustavo Palacios, Wanda Markotter}

We detected a high seroprevalence of Marburg virus (MARV) antibodies in fruit bats in South Africa; $19.1 \%$ of recaptured bats seroconverted. The MARV RNA isolated closely resembled the 1975 Ozolin strain. These findings indicate endemic MARV circulation in bats in South Africa and should inform policies on MARV disease risk reduction.

\begin{abstract}
A s of March 2018, thirteen outbreaks of Marburg virus (MARV) disease (MVD) have been reported, most occurring in sub-Saharan Africa $(1,2)$. The first recognized outbreak of MVD in Africa occurred in 1975 after a person hitchhiking through Zimbabwe was admitted to Johannesburg Hospital, Johannesburg, South Africa (3). The largest MVD outbreak occurred in Angola during 2004-2005 and had a case-fatality rate of $90 \%(4)$.

Outbreaks of MVD in Africa have been associated with persons entering caves or mines (5-8), and results of outbreak investigations and ecologic and experimental studies implicate the Egyptian rousette bat (Rousettus aegyptiacus) as the prime reservoir host for MARV (9-13). As part of a biosurveillance program in South Africa investigating the presence of viral zoonotic pathogens in bats, we tested a local population of Egyptian rousette bats for evidence of MARV infection.
\end{abstract}

\section{The Study}

At monthly intervals during February 2013-February 2014, we captured and sampled Egyptian rousette bats at the entrance to Matlapitsi Cave, also known as Mahune Cave. The cave is located in the indigenous flora of Matlapitsi Valley $\left(24^{\circ} 1^{\prime} \mathrm{S}, 30^{\circ} 10^{\prime} \mathrm{E}\right)$ on the northeastern slope of the Wolkberg

Author affiliations: National Institute for Communicable Diseases of the National Health Laboratory Service, Johannesburg, South Africa (J.T. Pawęska, P. Jansen van Vuren, A. Kemp, N. Storm, A.A. Grobbelaar); University of Pretoria, Pretoria, South Africa (J.T. Pawęska, P. Jansen van Vuren, N. Storm, W. Markotter); University of Nebraska Medical Center, Omaha, Nebraska, USA (M.R. Wiley); US Army Medical Research Institute of Infectious Diseases, Frederick, Maryland, USA (M.R. Wiley, G. Palacios)

DOI: https://doi.org/10.3201/eid2406.172165 mountain range, bordering Lekgalameetse Nature Reserve in Limpopo Province, South Africa. This work was done in accordance with approved protocols by animal ethics committees of the National Health Laboratory Service (Johannesburg, South Africa; AEC 137/12) and the University of Pretoria (Pretoria, South Africa; EC054-14). We captured and handled bats using standard procedures (10) and determined sex and age by visual evaluation of size, pelage color, and reproductive status. We tattooed and sampled anesthetized bats and processed blood and tissue specimens as described previously (12). We collected blood samples monthly from a subset $(n=1,431)$ of the total population of Egyptian rousette bats sampled during the 13-month biosurveillance program. Blood sample collection varied from 61 samples/month (April 2013) to 197 samples/month (May 2013). In addition, we collected spleen and liver tissues from 159 bats (average collection rate 12 samples/month). During the study period, 63 bats were recaptured (average rate 5 bats/month). We placed blood and tissue specimens in cryovials and transported them in liquid nitrogen to a biosafety level 4 facility for $-70^{\circ} \mathrm{C}$ storage until testing.

We performed serologic, molecular, and virologic testing as described previously (12) and used real-time quantitative reverse transcription PCR (qRT-PCR) targeting the MARV L and VP40 genes to identify MARV-positive bats (12). When performing qRT-PCR with serum samples, we used pooled samples from 3-5 bats. We attempted virus isolation with samples that were positive for the MARV genome. We sequenced virus genomes using the TruSeq RNA Access Kit (Illumina Inc., San Diego, CA, USA) with enrichment probes designed against multiple MARV strains, including the 1975 Ozolin strain, and sequenced on an Illumina MiSeq (14). We performed sequence alignment using MAFFT version 7.222 (https://mafft.cbrc.jp/alignment/ software/) and phylogenetic analysis using MrBayes version 3.2.6 (http://mrbayes.sourceforge.net/download.php).

Mating in the Egyptian rousette bat colony at Matlapitsi Cave occurred during June through midSeptember. The first neonates were observed in the second half of October. In December and January, almost all female bats captured carried an infant or were pregnant. Neonates were observed occasionally in March and April, outside the birthing season,

${ }^{1}$ Some preliminary results from this study were presented at the 6th International Symposium on Filoviruses; March 30-April 2, 2014; Galveston, Texas, USA. 
Figure 1. Marburg virus seropositivity in Egyptian rousette bats in Matlapitsi Cave, Limpopo Province, South Africa, 2013-2014. Numbers in parentheses indicate number of bats sampled per month. Bats $<1$ year of age (young bats) represent the new generation of bats born mostly during the October-January birthing peak. Statistically significant differences in seropositivity between adult and young bats are noted over a period of 4 months, April-July 2013.

*Significant difference $(p=0.0001)$ between adult and young bat populations. †Significant difference $(p=0.002)$ between adult and young bat populations.

suggesting asynchronous births. In previous studies, the Egyptian rousette bat population in Matlapitsi Cave was estimated to fluctuate from 3,270 to 9,000 bats, with the lowest numbers occurring during the winter months (15).

Of 1,431 bats tested, $759(53.04 \%)$ were positive for antibodies against MARV; overall seropositivity ranged from 14.75\% in April 2013 to 82.1\% in October 2013. Seropositivity in adults $(\mathrm{n}=784)$ was $71.56 \%$, ranging from 39.6\% in August 2013 to $100 \%$ in February 2013. Seropositivity in young bats $(\mathrm{n}=647)$ was $30.6 \%$, ranging from $1.3 \%$ in June 2013 to $77.3 \%$ in January 2014. Seropositivity was significantly higher in adult than young bats $(\mathrm{p}=0.002)$, especially during April 2013-July $2013(\mathrm{p}=$ $0.0001)$ (Figure 1). In total, $45.3 \%$ of male bats $(\mathrm{n}=592)$ and $58.5 \%$ of female bats $(\mathrm{n}=839)$ were seropositive $(\mathrm{p}=$ $0.667)$. Seroconversion was detected in $12(19.1 \%)$ of 63 recaptured bats. The bats that seroconverted were all juvenile bats on first capture (Table 1).

All serum pools tested by qRT-PCR were negative for both L and VP40 genes. Of the 159 liver-spleen tissue pools tested, $3(1.89 \%)$ were positive for MARV RNA: specimen no. SPU191/13 from a juvenile female bat (no. 2,764) captured in July 2013 (cycle threshold $\left[\mathrm{C}_{\mathrm{t}}\right]$ L 29.84, C VP40 31.58); specimen no. SPU249/13 from a juvenile male bat (no. 3,003) captured in August 2013 (C L 34.86, C VP40 33.85); and specimen no. SPU282/13 from a juvenile male bat (no. 3,092) captured in September $2013\left(\mathrm{C}_{\mathrm{t}} \mathrm{L}\right.$ 33.04, $\mathrm{C}_{\mathrm{t}} \mathrm{VP} 40$ 34.05). Attempts to culture the virus from qRT-PCR-positive tissue pools were unsuccessful. A similar ecologic study conducted in Uganda obtained identical results from bat tissues with $\mathrm{C}_{\mathrm{t}} \mathrm{s}>30$ (11).

Genomic analysis was performed only with the specimen with the lowest qRT-PCR $\mathrm{C}_{\mathrm{t}}$ (bat no. 2,764; SPU191/13). The MARV sequence detected (GenBank accession no. MG725616) was closely related to the 1975 Ozolin strain $(99.3 \%$ nucleic acid homology, $0 \%-1.2 \%$ amino acid differences) (Table 2; Figure 2). Only 22 aa substitutions were identified between these 2 viruses, which were isolated 38 years apart.

\begin{tabular}{|c|c|c|c|c|c|c|}
\hline \multirow[b]{2}{*}{ Bat no. } & \multicolumn{2}{|c|}{ First capture } & \multicolumn{2}{|c|}{ Second capture } & \multicolumn{2}{|c|}{ Third capture } \\
\hline & ELISA, \% positivity* & Capture date & ELISA, \% positivity* & Capture date & ELISA, \% positivity* & Capture date \\
\hline 243 & 8.48 & 2013 Mar 13 & 5.26 & 2013 May 13 & 67.15 & 2013 Aug 13 \\
\hline 287 & 13.75 & 2013 Apr 13 & 45.67 & 2013 Nov 13 & & \\
\hline 310 & 7.11 & 2013 Apr 13 & 36.41 & 2013 Jul 13 & & \\
\hline 323 & 11.30 & 2013 Apr 13 & 53.94 & 2013 Feb 14 & & \\
\hline 525 & 6.22 & 2013 May 13 & 42.61 & 2013 Jun 13 & & \\
\hline 542 & 7.19 & 2013 May 13 & 67.97 & 2013 Aug 13 & 100.69 & 2013 Nov 13 \\
\hline 615 & 4.91 & 2013 Jun 13 & 31.68 & 2013 Oct 13 & & \\
\hline 633 & 7.58 & 2013 Jun 13 & 53.93 & 2013 Jul 13 & & \\
\hline 653 & 4.53 & 2013 Jun 13 & 64.19 & 2013 Nov 13 & & \\
\hline 694 & 7.58 & 2013 Jun 13 & 4.24 & 2013 Sep 13 & 42.73 & 2013 Nov 13 \\
\hline 742 & 5.72 & $2013 \mathrm{Jul} 13$ & 23.82 & 2013 Oct 13 & & \\
\hline 822 & 6.86 & 2013 Jun 13 & 41.97 & 2014 Jan 14 & & \\
\hline
\end{tabular}


Table 2. Base pair changes between reference MARV strains and MARV from Matlapitsi Cave, Limpopo Province, South Africa, $2013^{*}$

\begin{tabular}{|c|c|c|c|c|}
\hline \multirow[b]{2}{*}{ Sequence type, MARV gene } & \multicolumn{4}{|c|}{ Strain, no. (\%) } \\
\hline & Ozolin 1975 & Angola 2005 & Musoke 1980 & Uganda 2009 \\
\hline \multicolumn{5}{|l|}{ Nucleotide sequence } \\
\hline Nucleocapsid & $9(0.43)$ & $120(5.8)$ & $112(5.4)$ & $123(5.9)$ \\
\hline Viral protein 35 & $4(0.43)$ & $56(5.7)$ & $37(3.7)^{\prime}$ & $58(5.9)$ \\
\hline Viral protein 40 & $5(0.57)$ & $54(5.9)$ & $50(5.5)$ & $52(5.7)$ \\
\hline Glycoprotein & $17(0.85)$ & $198(9.7)$ & $185(9.0)$ & $190(9.3)$ \\
\hline Viral protein 30 & $4(0.48)$ & $55(6.5)$ & $49(5.8)$ & $55(6.5)$ \\
\hline Viral protein 24 & $2(0.26)$ & $43(5.7)$ & $38(5.0)$ & $34(4.4)$ \\
\hline Polymerase & $43(0.6)$ & $469(6.7)$ & $425(6.1)$ & $479(6.8)$ \\
\hline \multicolumn{5}{|l|}{ Amino acid sequence } \\
\hline Nucleocapsid & 0 & $11(1.6)$ & $12(1.7)$ & $11(1.6)$ \\
\hline Viral protein 35 & 0 & $4(1.3)$ & $1(0.3)$ & $4(1.3)$ \\
\hline Viral protein 40 & $1(0.34)$ & $4(1.4)$ & $3(1.0)$ & $3(1.0)$ \\
\hline Glycoprotein & $8(1.2)$ & $60(8.8)$ & $61(9.0)$ & $63(9.3)$ \\
\hline Viral protein 30 & $1(0.36)$ & $8(2.9)$ & $13(4.7)$ & $10(3.6)$ \\
\hline Viral protein 24 & 0 & $2(0.79)$ & $2(0.79)$ & $1(0.4)$ \\
\hline Polymerase & $12(0.52)$ & $83(3.6)$ & $87(3.7)$ & $87(3.7)$ \\
\hline
\end{tabular}

\section{Conclusions}

Our findings indicate endemic MARV circulation in bats in Matlapitsi Cave, located $111 \mathrm{~km}$ from Polokwane City, South Africa's largest urban center north of Gauteng Province. Matlapitsi Cave, a 400-m hike from the main road running through the rural community of Fertilis, is accessible to humans. The cave was used in the past for religious practices and circumcision rituals, which have since been discontinued. In spite of their discontinuation, we found human shoe prints, litter, and signs of recent fire pit use at the cave entrance during our sampling trips. Informal discussions with persons of the local communities indicated that bats were not being hunted and their meat was not being consumed by local residents. However, uncontrolled migration of persons from neighboring countries where bat meat is consumed and increasing economic pressures, which could force local persons to hunt wildlife, might put the population at increased risk for MVD.

Observations made in this study confirm a distinctly seasonal Egyptian rousette bat reproductive period as previously reported (15). Gradual loss of passive immunity increases the number of susceptible bats, thus creating suitable conditions

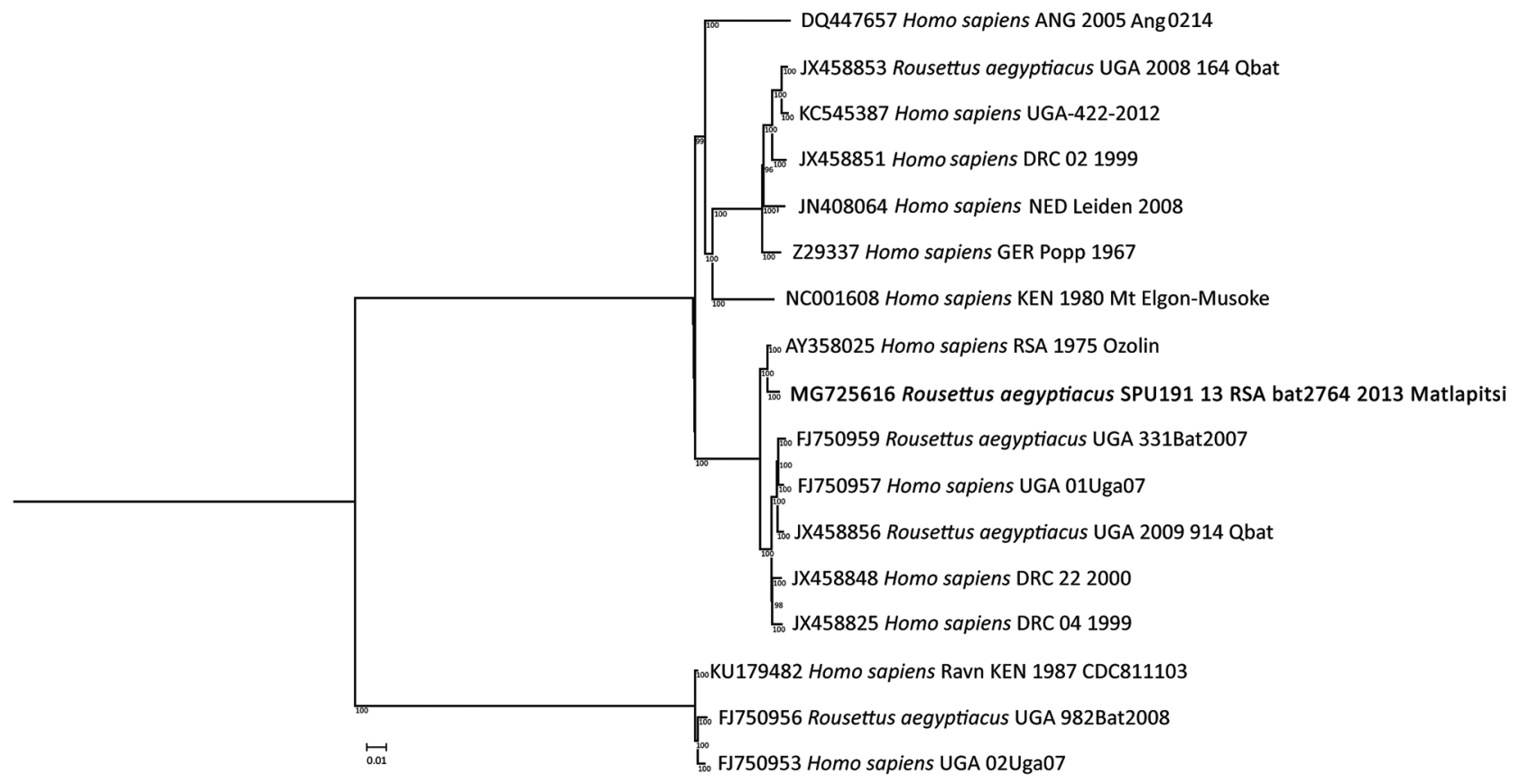

Figure 2. Phylogenetic tree of partial (97.5\%) Marburg virus nucleic acid sequence detected in Egyptian rousette bats in Matlapitsi Cave, Limpopo Province, South Africa, 2013 (bold; GenBank accession no. MG725616) and complete nucleic acid sequences of representative Marburg virus strains from GenBank. Node values indicate posterior probability percentages obtained from 1,000,000 generations in MrBayes version 3.2.6 (http://mrbayes.sourceforge.net/download.php). Scale bar indicates nucleotide substitutions per site. 
for MARV spread in the colony. Results of our study suggest that the single but relatively long birthing season complemented by asynchronous births and potential migration of bats might contribute to sustained annual MARV circulation in this area (15). These findings appear to be in contrast with those from the study in Uganda, which indicated that 2 yearly birthing seasons were required to maintain circulation of MARV in Egyptian rousette bats (11). The period of lowest seropositivity in young bats (April-July) might indicate a period of increased risk for exposure and shedding. The MARV sequence from the Matlapitsi Cave is phylogenetically most closely related to the Ozolin MARV strain, suggesting this variant has persisted in the southern part of Africa relatively unchanged since first discovered in 1975 (3). These findings contribute to our knowledge of MARV ecologic factors that could lead to a zoonotic spillover into humans and, thus, assist in the development of evidence-based policies for MVD risk reduction in South Africa.

\section{Acknowledgments}

We thank the staff and students of the Centre for Viral Zoonoses, University of Pretoria, and the staff of the Center for Emerging Zoonotic and Parasitic Diseases, National Institute for Communicable Diseases, National Health Laboratory Service, for technical assistance during field work. We also thank the local community leaders and municipality for their assistance.

This study was supported by the Global Disease Detection Program of the Centers for Disease Control and Prevention (grant no. GDD 5U19 GH000571-05/96667), South African National Research Foundation (grant no. UID 98339), and Poliomyelitis Research Foundation (12/14). The research was also partially supported by the US Defense Threat Reduction Agency (CB10246), Targeted Acquisition of Reference Materials Augmenting Capabilities Initiative, and US Defense Biological Product Assurance Office (task order award FA460012-D-9000). The content of this publication does not necessarily reflect the views or policies of the US Army or the US Department of Defense.

\section{About the Author}

Dr. Pawęska is the head of the Center for Emerging Zoonotic and Parasitic Diseases and the director of the World Health Organization Collaborating Center for Reference and Research on Viral Haemorrhagic Fevers and Arboviruses at the National Institute for Communicable Diseases, Johannesburg, South Africa. His research interests include diagnostics, epidemiology, and ecology of Biosafety Level 4 viral agents.

\section{References}

1. Amman BR, Swanepoel R, Nichol ST, Towner JS. Ecology of filoviruses. Curr Top Microbiol Immunol. 2017;411:23-61. http://dx.doi.org/10.1007/82_2017_10
2. World Health Organization. Marburg virus disease-Uganda. 2017 Oct 25 [cited 2017 Dec 28] http://www.who.int/csr/don/ 25-october-2017-marburg-uganda/en/

3. Gear JSS, Cassel GA, Gear AJ, Trappler B, Clausen L, Meyers AM, et al. Outbreake of Marburg virus disease in Johannesburg. BMJ. 1975;4:489-93. http://dx.doi.org/10.1136/ bmj.4.5995.489

4. Towner JS, Khristova ML, Sealy TK, Vincent MJ, Erickson BR, Bawiec DA, et al. Marburgvirus genomics and association with a large hemorrhagic fever outbreak in Angola. J Virol. 2006;80:6497-516. http://dx.doi.org/10.1128/JVI.00069-06

5. Smith DH, Isaacson M, Johnson KM, Bagshawe A, Johnson BK, Swanapoel R, et al. Marburg-virus disease in Kenya. Lancet. 1982;319:816-20. http://dx.doi.org/10.1016/ S0140-6736(82)91871-2

6. Centers for Disease Control and Prevention. Imported case of Marburg hemorrhagic fever-Colorado, 2008. MMWR Morb Mortal Wkly Rep. 2009;58:1377-81.

7. Timen A, Koopmans MP, Vossen AC, van Doornum GJ, Günther S, van den Berkmortel F, et al. Response to imported case of Marburg hemorrhagic fever, the Netherlands. Emerg Infect Dis. 2009;15:1171-5. http://dx.doi.org/10.3201/eid1508.090015

8. Bausch DG, Nichol ST, Muyembe-Tamfum JJ, Borchert M, Rollin PE, Sleurs H, et al.; International Scientific and Technical Committee for Marburg Hemorrhagic Fever Control in the Democratic Republic of the Congo. Marburg hemorrhagic fever associated with multiple genetic lineages of virus. N Engl J Med. 2006;355:909-19. http://dx.doi.org/10.1056/NEJMoa051465

9. Swanepoel R, Smit SB, Rollin PE, Formenty P, Leman PA, Kemp A, et al.; International Scientific and Technical Committee for Marburg Hemorrhagic Fever Control in the Democratic Republic of Congo. Studies of reservoir hosts for Marburg virus. Emerg Infect Dis. 2007;13:1847-51. http://dx.doi.org/10.3201/ eid1312.071115

10. Towner JS, Amman BR, Sealy TK, Carroll SAR, Comer JA, Kemp A, et al. Isolation of genetically diverse Marburg viruses from Egyptian fruit bats. PLoS Pathog. 2009;5:e1000536. http://dx.doi.org/10.1371/journal.ppat.1000536

11. Amman BR, Carroll SA, Reed ZD, Sealy TK, Balinandi S, Swanepoel R, et al. Seasonal pulses of Marburg virus circulation in juvenile Rousettus aegyptiacus bats coincide with periods of increased risk of human infection. PLoS Pathog. 2012;8:e1002877. http://dx.doi.org/10.1371/journal.ppat.1002877

12. Paweska JT, Jansen van Vuren P, Fenton KA, Graves K, Grobbelaar AA, Moolla N, et al. Lack of Marburg virus transmission from experimentally infected to susceptible in-contact Egyptian fruit bats. J Infect Dis. 2015;212(Suppl 2):S109-18. http://dx.doi.org/10.1093/infdis/jiv132

13. Amman BR, Jones MEB, Sealy TK, Uebelhoer LS, Schuh AJ, Bird BH, et al. Oral shedding of Marburg virus in experimentally infected Egyptian fruit bats (Rousettus aegyptiacus). J Wildl Dis. 2015;51:113-24. http://dx.doi.org/10.7589/2014-08-198

14. Ladner JT, Wiley MR, Mate S, Dudas G, Prieto K, Lovett S, et al. Evolution and spread of Ebola virus in Liberia, 2014-2015. Cell Host Microbe. 2015;18:659-69. http://dx.doi.org/10.1016/ j.chom.2015.11.008

15. Jacobsen NHG, du Plessis E. Observations on the ecology and biology of the Cape fruit bat Rousettus aegyptiacus leachi in the eastern Transvaal. S Afr J Sci. 1976;72:270-3.

Address for correspondence: Janusz T. Pawęska, Center for

Emerging Zoonotic and Parasitic Diseases, National Institute for

Communicable Diseases of the National Health Laboratory Service,

1 Modderfontein Rd, Sandringham 2131, Johannesburg, South Africa; email: januszp@nicd.ac.za 